\title{
FACTORS INFLUENCING FARMERS' DECISION TO INCREASE BEEF CATTLE BUSINESS SCALE IN CENTRAL JAVA PROVINCE
}

\author{
W. Roessali ${ }^{1}$, Masyhuri ${ }^{1}$, S. Nurtini ${ }^{2}$ and D.H. Darwanto ${ }^{1}$ \\ ${ }^{1}$ Faculty of Agriculture, Gadjah Mada University \\ Jl. Flora, Bulaksumur Campus, Yogyakarta-Indonesia \\ Permanent Address: Faculty of Animal Agriculture, Diponegoro University, \\ Tembalang Campus, Semarang 50275 - Indonesia \\ ${ }^{2}$ Faculty of Animal Science, Gadjah Mada University, \\ Jl. Fauna, Bulaksumur Campus, Yogyakarta - Indonesia \\ CorrespondingE-mail: wroessali@gmail.com
}

Received November, 2010; Accepted February 20, 2011

\begin{abstract}
The purpose of this research was to analyze factors influencing farmers' decision to increase beef cattle business scale through improved technology. The research was conducted by using a survey method. Five districts were purposively selected in three base areas and two non-base areas of beef cattle in Central Java Province, Indonesia. Twenty beef cattle groups were selected based on the largest cattle population managed and their performance, while 196 respondents were randomly selected. Farmers' decision to increase beef cattle business scale was determined using a probit model. Result of the research indicated that the number of family labor and expectation to increase income had a significantly positive influence on the farmers' decision to increase beef cattle business scale. It meant that if the total number of family labor increased, so did the farmers' decision to increase the beef cattle business scale. Also, if the expectation to revenue increased, so did the farmers' decision to increase the beef cattle business scale. On the contrary, education level and business risk had negative significant influence on the farmers' decision to increase the beef cattle business scale with the significance levels of 1.1 and 0.84 , respectively.

Keywords: beef cattle, decision, probit model, small-scale farmer
\end{abstract}

\section{INTRODUCTION}

Cattle business is a process of combining some production factors of land, livestock, labor, and capital to produce cattle-based products. In fact, the success of cattle business depends on three elements, i.e. breed, feed, and management. The management of cattle business includes the management of breeding, feeding, housing, and health of livestock, as well as labor preparation, livestock handling, and the marketing of cattlebased products. However, the traditional cattle rearing system is mostly characterized by a low level of input in a small business scale.

In a traditional management system, farmers do not apply technologies for improving feed quality, so the goal of cattle business for profit frequently fails to achieve. Dorfman (1996) stated that there were two main areas of technology adoption, i.e. in building an economic decision model in relation to factors such as farm size, attitude toward risk, and liquidity, and in empirical studies identifying factors associated with adoption decision. Moreover, Baidu-Forson (1999) stated that farmers' decision to adopt technology was highly influenced by their attributes, farm size, perception on technology, and agricultural infrastructure. According to Turner et al. (1992), many decisions made by the managers of cow calf operation directly influence the profitability of cattle business. Just and Zilberman (1983) argued that there was a relationship between economic size and technology adoption and the quadratic effect was possible to occur, because large businesses were prone to adopt new technology earlier than smaller ones. However, Koundouri et al. (2006) stated that agricultural technology adoption has been examined under uncertainty.

The research was ever conducted in the same area in terms of determining the level of rice straw fermentation technology adoption. Result of 
the research indicated that farmers give high responses $(25.24 \%)$, and the remaining was classified in medium and low responses $(23.88 \%)$. Factors with significant positive influence on rice straw-based feed processing technology adoption are the number of family labor, distance from forage feed source, business goal, and the level of participation as member of the farm group. However, other factors such as annual income, time allocation, and production area had significantly negative influence to adopt the rice straw-based feed processing technology.

In fact, management should encourage cattle farmers to increase the cattle business scale. The increase of business scale was influenced by factors, including input, production, market, economic cost, and tax consideration. The risk behind the probability of any events or conditions had adverse consequences at any stages in the course of production chains (Pasaribu and Syukur, 2010). In the small scale cattle business, farmers were frequently reluctant to increase their production scale due to internal business constraints, including capital, access to credit (Sudaryanto and Rusastra, 2006), and limited labor (Priyanti et al., 2007).

Therefore, it can be stated that farmers' capacity to adopt new technology for increasing cattle productivity depends on resources available, socio-economic characteristics, and external factors that was uncontrolled by farmers. All of the variables are assumed to influence farmers' decision to increase cattle business scale, so the purpose of this research is to analyze factors influencing the farmers' decision to increase cattle business scale.

\section{MATERIALS AND METHODS}

The research was conducted as a follow-up of the previous survey to cattle farmer household (Roessali et al., 2009). A structured questionnaire was used to collect information on the socioeconomic characteristics of farmer household, which were considered to affect the small scale farmers' decision to increase beef cattle production. A survey method was used in five districts purposively selected on the base of largest population in Central Java Province, Indonesia. Of the five districts selected, ten subdistricts were selected by using a purposive sampling technique. Twenty beef cattle reared in group were selected based on the largest population managed and their performance, while
196 respondents were randomly selected. The data were collected in the period of January to February 2009.

A probit model was used to determine factors influencing the farmers' decision to increase the beef cattle business. A procedure to measure the farmers' decision was to apply both binary and non-binary variables for quantifying factors mostly influencing positive or negative decisions of the farmers to increase beef cattle production. A probit procedure that specifies the binary dependent variable as a function of the number of quantitative explanatory variables was used for the ability of generating bounded probability estimates for individual farmer (Hill and Kau, 1973; Borooah, 2002; Koundouri, 2006). Table 1 shows factors influencing the farmers' decision in the model of Pindyck and Rubinfeld (1991) expressed as follow :

$$
Y_{i}=\alpha+\beta X_{i}+\varepsilon_{i}
$$

where $X_{i}$ represents vectors of $\mathrm{n}$ explanatory variable of the $\mathrm{i}^{\text {th }}$ farmer; $Y_{i}$ is a binary variable such that $Y_{i}=1$ if the $\mathrm{i}^{\text {th }}$ farmer wants to expand production, and $Y_{i}=0$ if otherwise. In the model, $X_{i}$ is assumed to be stochastic and independent of the zero mean random variable $\varepsilon_{\mathrm{i}}$. $Y_{i}$ can be only assumed to two different values, i.e. 0 and 1 , so the expected probability could be obtained:

$E\left(Y_{i}\right)=1 X f_{i}(1)+0 X f_{i}(0)=f_{i}(1)$

where $f_{i}$ (1) is the probability of expanding operation for a farmer with a set of resources and economic characteristics $\left(\mathrm{X}_{\mathrm{i}}\right)$. From (1) and (2),

$E\left(Y_{i}\right)=\alpha+\beta X_{i}$

meaning that the probability $f_{i}$ (1) would be different for farmers with different levels of resources and economic characteristics. Thus, the expected probability $E\left(Y_{i}\right)$, which could be interpreted as the proportion of all farmers with resources and economic characteristics $\left(\mathrm{X}_{\mathrm{i}}\right)$ mostly increasing production scale, would be:

$0 \leq \alpha+\beta X_{i} \leq 1$

Following Deressa (2008), general probit model form for the $i^{\text {th }}$ farmer was: 


\begin{tabular}{|c|c|c|}
\hline $\begin{array}{l}\text { Explanatory } \\
\text { Variable }\end{array}$ & Explanation & Expected Sign \\
\hline HERD & Actual number of cattle reported & - \\
\hline LAND & Land area containing pastures for grazing & + \\
\hline LABOR & $\begin{array}{l}\text { Actual number of persons working on farm at least half time (no. of hired and } \\
\text { family labor) }\end{array}$ & + \\
\hline EDU & $\begin{array}{l}\text { Dummy variable indicating whether or not the producer has a high school } \\
\text { education above ( } 1=\text { yes, } 0=\text { otherwise). }\end{array}$ & + \\
\hline AGE & Actual age of farmer & - \\
\hline INC & Actual gross income reported from sales of beef cattle (IDR) & + \\
\hline EXPT & $\begin{array}{l}\text { Dummy variable indicating whether or not the farmer monitors beef cattle } \\
\text { futures prices on at least a weekly basis }(1=\mathrm{yes}, 0=\text { otherwise). }\end{array}$ & + \\
\hline RISK & $\begin{array}{l}\text { Dummy variable indicating whether or not the producer is risk averse }(1=\text { yes, } \\
0=\text { otherwise). Risk averse is that having a lower score than the average score. }\end{array}$ & - \\
\hline ADOPT & $\begin{array}{l}\text { Dummy variable indicating whether the farmer would adopt or not. }(1=\text { adopt, } \\
0=\text { otherwise }) \text {. }\end{array}$ & + \\
\hline
\end{tabular}

DECI $=\mathrm{f}($ HERD, LAND, LABOR, EDU, AGE, INC, EXPT, RISK, ADOPT)

The dependent variable was a hypothetical index signifying the farmers' decision to increase cattle production. The Maximum Likelihood (ML) technique was used to estimate the coefficient of beef cattle business scale (Gujarati, 1978). The present study used the probit model. Meanwhile, the independent variables in the model with expected signs are presented in Table 1. To test a null hypothesis that all the explanatory variables did not simultaneously influence the dependent variable, the statistical Likelihood Ratio (LR) was used as the F test on the OLS method. The value of LR statistics followed the chi-square $\left(X^{2}\right)$ with a degree of freedom (df) of the explanatory variables excluding the constant. If the chi-square value $\left(X^{2}\right)$ was greater than the critical value (table), the null hypothesis was rejected, meaning that all the explanatory variables simultaneously influence the dependent variable, and vice versa. Moreover, the binary model did not use the value of coefficient determination $\left(\mathrm{R}^{2}\right)$ conventionally applied to measure the goodness of regression line, but did the coefficient one developed by Mc-Fadden $\left(\mathrm{R}_{\mathrm{McF}}^{2}\right)$, where the value is between 0 and 1 (Widarjono, 2007). The data collected were analyzed by using the Eviews software version 5 .

\section{RESULTS AND DISCUSSION}

\section{Socio-economic Characteristics of Farmers}

Data of the socio-economic characteristics of farmers are shown in Table 2, indicating that most beef cattle farmers were male $(86.73 \%)$ with age groups distribution of less than 35 years old, 3655 years and more than 55 years were 23.47, 55.61 and $20.9 \%$, respectively. Approximately, $95.5 \%$ of the respondents had formal education, of which $13.37 \%$ was graduated from senior high school, 3.74\% from college, and 96.4\% married. Most respondents (61.4\%) were generally had 1625 years of experience in raising beef cattle, while $14.3 \%$ was less than five years. Family size was 3.05 people in average, where $86.7 \%$ was less than four members, while labor was generally from the family members $(83.7 \%)$. Most of the respondents $(62.2 \%)$ had average income of IDR 10.1-30 millions annually, and 2.5-5.0 millions $(62.2 \%)$ were derived from beef cattle rearing. The main sources of passive income were offfarm employment (38.8\%), pension (12.8\%), and small business such as retailer or trader $(12.8 \%)$. According to Arfai et al. (2009) cattle business was not a main business with contribution of less than $30 \%$ of total income. 
Table 2. Characteristic of Farmer in Five Districts in Central Java

\begin{tabular}{|c|c|c|c|c|c|c|}
\hline Characteristic & Wonogiri & Grobogan & Blora & Semarang & Kendal & Total \\
\hline \multicolumn{7}{|l|}{ Gender (\%) } \\
\hline Male & 17.35 & 17.35 & 19.39 & 16.33 & 16.33 & 86.73 \\
\hline Female & 2.04 & 3.06 & 1.02 & 3.06 & 4.08 & 13.27 \\
\hline Married (\%) & 18.88 & 19.39 & 19.39 & 18.37 & 20.41 & 96.43 \\
\hline \multicolumn{7}{|l|}{ Age of respondent (\%) } \\
\hline Less than 35 years & 6.12 & 7.14 & 5.10 & 5.10 & 0.00 & 23.47 \\
\hline $36-55$ years & 12.24 & 10.71 & 10.20 & 5.10 & 17.35 & 55.61 \\
\hline More than 55 years & 5.10 & 4.08 & 5.61 & 3.06 & 3.06 & 20.92 \\
\hline \multicolumn{7}{|l|}{ Education level (\%) } \\
\hline No Formal Education & 4.08 & 3.06 & 4.08 & 3.06 & 2.04 & 16.33 \\
\hline \multicolumn{7}{|l|}{ Formal School } \\
\hline 6 years & 7.65 & 7.65 & 9.18 & 8.67 & 8.16 & 41.33 \\
\hline 9 years & 4.08 & 4.59 & 6.12 & 6.12 & 4.59 & 25.51 \\
\hline 12 years & 1.53 & 3.06 & 1.02 & 3.57 & 4.08 & 13.27 \\
\hline College & 0.51 & 0.51 & 1.02 & 1.02 & 0.51 & 3.57 \\
\hline Average Family size (person) & 3.12 & 3.00 & 3.05 & 2.95 & 3.12 & 3.05 \\
\hline \multicolumn{7}{|l|}{ Farming experience (\%) } \\
\hline Less than 10 years & 1.02 & 0.00 & 1.02 & 5.10 & 5.10 & 12.24 \\
\hline $11-15$ years & 3.06 & 5.10 & 7.65 & 1.02 & 1.53 & 18.37 \\
\hline $16-20$ years & 4.08 & 6.63 & 7.65 & 4,08 & 3.06 & 25.51 \\
\hline $21-25$ years & 7.65 & 11.22 & 10.20 & 4.08 & 2.55 & 35.71 \\
\hline More than 25 years & 2.04 & 3.06 & 2.04 & 1.02 & 0.00 & 8.16 \\
\hline \multicolumn{7}{|l|}{ Average cattle ownership (\%) } \\
\hline Less than 2 heads & 10.20 & 7.65 & 9.69 & 11.22 & 11.73 & 50.51 \\
\hline $2.1-3.0$ heads & 5.61 & 6.63 & 7.65 & 4.08 & 6.12 & 30.10 \\
\hline More than 3.1 heads & 3.57 & 6.12 & 3.06 & 4.08 & 2.55 & 19.39 \\
\hline \multicolumn{7}{|l|}{ Annual income (\%) } \\
\hline Less than 5 million & 2.55 & 3.06 & 3.06 & 2.04 & 2.55 & 13.27 \\
\hline 5.1-10 million & 4.08 & 6.12 & 3.06 & 8.67 & 2.55 & 24.48 \\
\hline 10.1-15 million & 7.14 & 9.19 & 11.23 & 3.57 & 6.63 & 37.76 \\
\hline More than 15.1 million & 4.08 & 6.12 & 3.06 & 8.67 & 2.55 & 24.48 \\
\hline
\end{tabular}

Most of the beef cattle farmers $(89.9 \%)$ were suggested to rear beef cattle by governmental apparatuses or academic staff for at least two times a year. Many of them mutually exchange suggestions on how to rear the beef cattle in group. It was found out that half of the beef cattle farmers $(63.8 \%)$ were in the low level of adoption to all the items of beef cattle rearing management practices (Table 3), including beef cattle health (disease prevention and healing), breeding (artificial insemination), environmental management (housing, feces treatment, 
Table 3. Percentage of Risk and Adoption Score

\begin{tabular}{|c|c|c|c|c|c|c|c|}
\hline \multirow{2}{*}{ Risk and Adoption } & \multicolumn{2}{|c|}{ High } & \multicolumn{2}{|c|}{ Medium } & \multicolumn{2}{|c|}{ Low } & \multirow{2}{*}{ Total } \\
\hline & Person & $\%$ & Person & $\%$ & Person & $\%$ & \\
\hline \multicolumn{8}{|l|}{ Response to risk } \\
\hline Investment & 10 & 5.10 & 16 & 8.16 & 170 & 86,73 & 196 \\
\hline Fees/taxes & 12 & 6.12 & 16 & 8.16 & 168 & 85.71 & 196 \\
\hline Prices of output & 10 & 5.10 & 10 & 5.10 & 176 & 89.80 & 196 \\
\hline Price of input & 12 & 6.63 & 21 & 10.71 & 162 & 82.65 & 196 \\
\hline Average & 11 & 5.74 & 16 & 8.04 & 169 & 86.22 & \\
\hline \multicolumn{8}{|l|}{ Adoption technology } \\
\hline Health management & 26 & 13.27 & 54 & 27.55 & 116 & 59.18 & 196 \\
\hline Breeding management & 22 & 11.22 & 58 & 29.59 & 116 & 59.18 & 196 \\
\hline Feeding management & 22 & 11.22 & 62 & 31.63 & 112 & 57.14 & 196 \\
\hline Environmental management & 8 & 4.08 & 32 & 16.33 & 156 & 79.59 & 196 \\
\hline Average & 15.6 & 9.95 & 51.50 & 26.30 & 100 & 63.78 & \\
\hline
\end{tabular}

Table 4. Probit Regression of Farmers Exhibiting Positive Attitudes towards Increased Cattle Production

\begin{tabular}{|c|c|c|c|}
\hline Explanatory Variables & Estimated Coefficient & Standard Error & Probility \\
\hline CONSTANT & -7.445344 & 1.314790 & 0.0000 \\
\hline HERD & $-0.003146^{*}$ & 0.001794 & 0.0795 \\
\hline LAND & $0.003958^{\mathrm{NS}}$ & 0.006734 & 0.5567 \\
\hline LABOR & $2.212449^{* * *}$ & 0.365581 & 0.0000 \\
\hline EDU & $-1.109221^{* *}$ & 0.499141 & 0.0263 \\
\hline AGE & $-0.008168^{N S}$ & 0.015973 & 0.6091 \\
\hline INC & $-0.000224^{*}$ & 0.000117 & 0.0556 \\
\hline EXPT & $1.310144^{* *}$ & 0.559212 & 0.0191 \\
\hline RISK & $-0.840752^{*}$ & 0.447629 & 0.0603 \\
\hline ADOPT & $0.071443^{\mathrm{NS}}$ & 0.143299 & 0.6181 \\
\hline Log likehood & -45.18064 & & \\
\hline McFadden R-squared & 0.663151 & & \\
\hline
\end{tabular}

NS: Not Significant; ${ }^{*}$ Significant at $10 \%$ level; ${ }^{* *}$ Significant at $5 \%$ level; ${ }^{* * *}$ Significant at $1 \%$ level

composting), and feeding (quantity and quality of feed, feed treatment, and stock preparation).

One of the obstacles frequently encountered in the farming business was risk and uncertainty aspects, which should be considered in making decisions. The risks of decision taken into account 
in the study were the willingness of farmers to make investment in stock, to build a cowshed, to bear the compensation cost for cattle maintenance such as taxes, purchase of input and output, price risk (Table 3). As a whole, it was found that $86.22 \%$ of the respondents had a risk aversion, but almost half of them had positive expectation to increase the production scale if access to cheap loan was available.

\section{Correlation Analysis of Variables}

The possibility of farmers' decision to increase beef cattle business was estimated by using explanatory variables in the equation are shown in Table 4 . The result indicated that the number of family labor and expectation to increase income had a significant influence on the farmers' decision to increase the cattle business scale. Coefficients of both variables had the expected signs. Herd size, education level, income and risk had significantly negative influence, while land, age, and technology adoption did not influence the farmers' decision. It implies that the asset of family labor among the small scale farmers will mostly improve the possibility of increasing productivity and provide better opportunity for increased income in the future. Conversely, herd size, education level, annual income, and risk aversion had negative effect on the farmers' decision to increase the beef cattle business scale.

The coefficient of determination, $\mathrm{R}^{2}{ }_{\mathrm{McF}}$, 0.66 indicated that variation of $66 \%$ in the farmers' decision to increase the beef cattle business scale was explained by the nine variables included in the model. Result of the binary probit regression coefficient of factors influencing the farmers' decision are shown in Tabel 4. A positive sign of the coefficient of variables indicates that the higher the value of variables, the higher the possibility of farmers to increase the beef cattle business scale and vice versa. Log likelihood value was $45.18(p<0.01)$, indicating that the nine explanatory variables in the model simultaneously influenced the dependent variables.

It is hypothesized that current herd size was closely related to the farmers' decision to increase beef cattle business scale, because the probability of negative response increased for farmers with smaller herd size and vice versa. Herd size had influence $(\mathrm{p}<0.10)$, supported by this hypothesis. If the farmers have larger business scale, they will not increase the number of cattle due to the limited capacity and feed availability.

The availability of land was an important positive factor influencing the farmers' decision in the future. Result of the study did not support the hypothesis that farmers with land and superior grasses will increase the herd size compared to those with limited one. It was hypothesized that the availability of family labor had significantly positive influence on the farmers' decision to increase the beef cattle business scale. The number of family labor was a factor encouraging farmers with assets to improve a better beef cattle management. Most interviewed farmers lived with at least two members of family $(81.2 \%), 42.2 \%$ of which had four members and $5.8 \%$ more than four members, including hired labors. Family with large members could help performing the tasks of rearing the beef cattle, i.e. looking for forage, herd cleaning, etc. For farmers with a small area, the management of beef cattle kept the credible amount of feed, depending on the availability of family labor, particularly to look for forage. The implication was that the breeder could improve the business scale if forage could be collected in a large number.

Education level influenced the mastery of knowledge and technology in society. Traditional farming community was mostly characterized by the low level of education and knowledge. However, it was found that the coefficient of education level was negatively correlated $(p<0.05)$ with the farmers' decision to increase cattle business scale. It indicated that the higher level of education did not influence the farmers' decision to increase the business scale. The result was in line with that found by Hartono et al. (2006), indicating that the higher level of education encouraged the farmers in reducing their working time allocated to the cattle business. The highly educated farmers usually chose to work in nonagricultural sector with relatively higher level of income and having more prestigious socio-economic status, and therefore they had a limited time and practical ability on rearing numerous cattle. Moreover, Prasetyo et al. (2005) stated that the farmers with the lower level of education adopted less new technological innovations to apply in the cattle business.

In addition, it is hypothesized that age was also negatively correlated with the probability of positive response because older farmers was less vigorous than younger ones in farming. Result of the study indicated that the hypothesis could not be empirically verified, because the factor did not 
significantly influence the farmers' decision to increase cattle production. Based on the classification of both productive and nonproductive ages, it is known that the majority of respondents could be included in productive age category and the productive one significantly influenced the farmers' physical ability to work in an optimal manner.

Furthermore, it was hypothesized that income and expectation to increase income derived from cattle production and investment significantly influenced the farmers' decision to increase the cattle business scale. The more income to be reached, the more optimistic the farmers did any efforts of getting the future return realized. Income had a significantly negative influence $(\mathrm{p}<0.10)$ on the farmers' decision to increase the cattle business scale, indicating that the higher income to be reached, the higher tendency among farmers to reduce the working time allocated to increase the cattle business scale. For them, cattle were assets that can be sold when they urgently needed money. By implication, any commercially oriented approach applied by them to increase the cattle production will require substantially large initial cash input to purchase more cattle for better production, improved pastures, and adequate infrastructures. However, the annually income of the farmers was averaged IDR $3,073,660$, indicating that it was too low to meet the initial cost of increasing the cattle production.

In a case of uncertainty, expectation to income was considered as a mostly important factor with a positive correlation with farmers' decision to increase the cattle production. It is expected that producers with more experiences in the cattle business and awareness of the future market situations are able to make informed decisions on production. Frequently monitoring prices makes them able to use the knowledge of market as a part of the risk management strategies. The expectation to income was significant $(p<0.05)$, indicating that the factor positively influenced the farmers' decision to increase the beef cattle business.

The risk aversion was approximately $88.26 \%$, and it was hypothesized that the risk directly influenced the farmers' decision to increase the cattle business scale, so it has negatively influenced on the possibility of increasing the cattle production. It can be interpreted that the higher level of business risk will necessarily reduce the farmers' decision to increase the cattle business scale. Keeney and Raiffa (1993) argued that producers are willing to sacrifice higher expected returns to reduce risk. According to Meuwissen et al. (2001) price and production risk are perceived as important sources of risk, while Pasaribu and Syukur (2010) reported that the risk adversely affected the current and future farmers' decision to increase production and income.

Cattle number reared by farmers are the most important factor influencing income. But the constraints of capital and labor to make most of the farmers expressed only able to maintain a few cows. Thus, considering the ability to obtain or purchase forage, a family farmer was just able to rear less than five cattle. However, farmers in Central Java just owned 2-3 cattle in average, indicating that the ownership was in a small scale. It was estimated that there were just 617,000 cattle farmers in Central Java Province on 2009 (Dinas Peternakan dan Kesehatan Propinsi Jawa Tengah, 2010). The population of 1.5 million beef cattle was equal to 1.1 million heads, so the average herd size per farm of 2.5 cattle was equal to 1.86 animal unit on average (Roessali et al., 2010). Since the herd size was small, one of the efforts to increase the cattle production was to integrate cattle and crops. Diwyanto et al. (2002) and Priyanti et al. (2007) reported that the integration of cattle and crops will increase the output of farming system. Accordingly, Suppadit et al. (2006) stated that the effort was a good agricultural management practice.

\section{CONCLUSION}

Result of the study showed that the number of family labor and expectation to income had positive influence on the farmers' decision to increase the beef cattle production. In the contrary, herd size and education level, annual income, and farming risk had negative influence. The bigger the family labor, the more possible the farmers increase the cattle production. Expectation to increase income in the future from the cattle business with right investment will influence the great desire to increase the cattle production. Both the number of cattle reared and the higher level of education encouraged the farmers' decision to increase cattle business scale. In such socio-economic conditions, any constraints for technology adoption to increase the cattle production were exacerbated by the limited availability of family labor and working capital 
for adequate production management practices, particularly to meet the need for forage. With coupled husband and wife as the family labor, a family was just able to rear less than five cattle in average.

\section{REFERENCES}

Arfai, K. Wardhono, A.M. Fuah and A. Syaefuddin. 2009. Potensi pengembangan sapi potong dalam sistem usahatani di Kabupaten Lima Puluh Kota Sumatera Barat. J. Indonesian Trop. Anim. Agric. 34(1):65-73

Baidu-Forson, J. 1999. Factors influencing adoption of land-enhancing technology in the Sahel:lessons from a case study in Niger. Agricultural Economics. 20: 231-239

Borooah, V.K. 2002. Logit and Probit Ordered and Multinomial Models. Sage Publications. International Educational and Professional Publisher. Thousand Oaks London. New Delhi.

Deressa, T., R. M. Hassan, T. Alemu, M. Yesuf and C. Ringler. 2008. Analyzing the Determinants of Farmers' Choice of Adaptation Methods and Perceptions of Climate Change in the Nile Basin of Ethiopia. International Food Policy Research Institute Discussion Paper 00798. Page 1-26 (http://www.ifpri.org/sites/default/ files/publications/ ifpridp00798.pdf)

Dinas Peternakan dan Kesehatan Hewan Propinsi Jawa Tengah. 2010. Statistik Peternakan 2010. Ungaran, Jawa Tengah.

Diwyanto, K., B.R. Prawiradiputra and D. Lubis. 2002. Integrasi tanaman-ternak dalam pengembangan agribisnis yang berdaya saing, berkelanjutan dan berkerakyatan. Wartazoa. 12(1):1-8

Dorfman, J.H. 1996. Modeling multiple adoption decisions in a joint framework. A.J.A.E. 8(3):547-557.

Gujarati, D. 1978. Basic econometrics. McGrawHill Book Co., New York, N.Y.

Hartono, B. M. B. Mariyono and F. Rochman. 2006. Usaha ternak kambing sebagai alternative sumber pendapatan dan penyerapan tenaga kerja keluarga: studi di Desa Tamansari Kecamatan Ampelgading Kabupaten Malang Jawa Timur. J. Indonesian Trop. Anim. Agric. 31(2): 99-104

Hill, L. and P. Kau. 1973. Application of multivariate probit to a threshold model of grain dryer purchasing decisions. A.J.A.E.
55:19-27.

Just, R.E., and D. Zilberman. 1983. Stochastic Structure Farm Size, and Technology Adoption in Developing Agriculture. O.E.P. 3:307-328.

Keeney, R.L. and H. Raiffa. 1993. Decisions with Multiple Objectives: Preferences and Value Tradeoffs. Cambridge University Press.

Koundouri, P., C. Nauges and V. Tzouvelekas. 2006. Technology adoption under production uncertainty: theory and application to irrigation technology. A.J.A.E. 88(3):657670.

Meuwissen, M.P.M., R. B. M. Huirne and J. B. Hardaker. 2001. Risk and risk management: an empirical analysis of Dutch livestock farmers. Livestock Prod. Sci. 69(1):43-53

Pasaribu, S.M and M. Syukur. 2010. Policy support for climate risk adaptation: the role of microfinance. Analisis Kebijakan Pertanian. 8(1):1-11

Pindyck, R. S. and D. L. Rubinfeld. 1991. Econometric Models and Economic Forecast. McGraw-Hill, Inc. Page 249

Prasetyo, E. T. Ekowati and Mukson. 2005. Kondisi dan potensi pengembangan usahatani ternak sapi perah di Kabupaten Semarang. J. Indonesian Trop. Agric. 30(2):110-118

Priyanti, A., B.M. Sinaga, Y. Syaukat and S.U. Kuntjoro. 2007. Dampak program sistem integrasi tanaman-ternak terhadap alokasi waktu kerja dan pengeluaran rumahtangga petani. Disertasi. Sekolah Pascasarjana Program Studi Ekonomi Pertanian. Institut Pertanian Bogor

Roessali, W. Masyhuri, S. Nurtini and D.H. Darwanto. 2009. Faktor-faktor penentu tingkat adopsi teknologi pengolahan hijauan pakan ternak pada peternak sapi potong di Jawa Tengah. Agromedia. 27(1):42-51

Roessali, W. Masyhuri, S. Nurtini and D.H. Darwanto. 2010. Performance and foresight of beef cattle development in Central Java. Proceedings part 2 . The $5^{\text {th }}$ ISTAP International Seminar on Tropical Animal Production: Community Empowerment and Tropical Animal Industry. Yogyakarta, October 19-22. Page 795-801

Sudaryanto, T and I. W. Rusastra. 2006. Kebijakan strategis usaha pertanian dalam rangka peningkatan produksi dan pengentasan kemiskinan. Jurnal Litbang Pertanian. 25(4):155-122 
Suppadit, T., N. Phumkokrak and P. Poungsuk, 2006. Adoption of good agricultural practices For beef cattle farming of beef cattle - raising farmers in Tambon Hindard, and Khunthod district, Nakhon Ratchasima Province, Thailand, KMITL Sci. Tech. J. 6(2):67-73

Turner, S.C., J. C. McKissickt, M. A. McCann, and N. S. Dykes. 1992. Market Value and Managerial Decisions: Implications from a Decade of Feeder Cattle Teleauctions. J. Anim. Sci. 70:1015-1021

Widarjono, A. 2007. Ekonometrika Teori dan Aplikasi Untuk Ekonomi dan Bisnis. Edisi Kedua. Penerbit Ekonisia, Fakultas Ekonomi UII Yogyakarta. Page 217 